\title{
Levels of Serum Nerve Growth Factor in Autistic Children in Benha City
}

\author{
A.A.Abou Amer ${ }^{1}$, A.E.El-Sadek ${ }^{1}$, J.H.Sabry ${ }^{2}$ and Sh.T.El-Bakry ${ }^{3}$ \\ ${ }^{1}$ Pediatrics Dept., Faculty of Medicine, Benha Univ., Benha, Egypt \\ ${ }^{2}$ clinical and chemical pathology Dept., Faculty of Medicine, Benha Univ., Benha, Egypt \\ ${ }^{3}$ Neuropsychiatry Dept., Faculty of Medicine, Benha Univ., Benha, Egypt \\ E-Mail:fatma85@gmail.com
}

\begin{abstract}
It has been hypothesized that abnormal levels of serum nerve growth factor (NGF) may represent a serological marker for autistic children. The objective of this study was to measure serum NGF concentrations of autistic children and compare these levels with those of healthy children. We incorporated 20 mentally unbalanced know youngsters in the patients group, same time 20 sound kids were incorporated Concerning illustration controls. Then afterward history bringing Furthermore physical examination, serum ngf levels were measured for patients and control aggregations. No critical Contrast might have been distinguished the middle of patients Furthermore controls $(\mathrm{p}>0.05)$. Serum ngf might have been essentially lifted in the patients assembly contrasted with controls (220. 0 vs. $140.0, \mathrm{p}<0.001)$, and it needed a affectability about $85 \%$ What's more An specificity for $76 \%$ The point when its level will be higher over $185.5 \mathrm{pg} / \mathrm{ml}$. Moreover, serum ngf might have been fundamentally higher done cases with sure historical backdrop from claiming issues Throughout pregnancy and conception difficulties $(\mathrm{P}<0.001)$. Our outcomes indicated that serum ngf focuses might make utilized Likewise An possibility symptomatic device over autism, however, further investigations including an expansive number about patients would needed to affirm those discoveries.
\end{abstract}

\section{Introduction}

A mental imbalance range jumble (ASD) is An neurodevelopmental jumble portrayed Toward impeded social communication, repetitive, or stereotyped practices Also low investment to earth jolts [1].

Patients for ASD bring maladjustment clinched alongside enthusiastic response, anxiety, impeded passionate learning, set enthusiasm toward encompassing environment, Furthermore deficiency over correspondence What's more social cooperations. ASD pathology need a few copartnered indications that are created Eventually Tom's perusing comorbid issue. These comorbid indications frequently all the include: seizures, anxiety, scholarly impairment, hyperactivity, hyper alternately hyporesponsiveness to stimulus, rest disruption, Forceful behavior, and so forth throughout this way, observing and stock arrangement of all instrumentation may be enha. Consequently, ASD will be viewed as an intricate jumble for paramount epigenetic parts [2].

The nerve development component (NGF), a part from claiming neurotrophin family, might have been Initially portrayed Toward levi Montalcini Furthermore associates over 1951. It need been guessed that abnormal levels about serum ngf might speak to An serological marker to mentally unbalanced Youngsters who might create cognitive hindrance What's more relapse [3].

Since development Components (GFs) control different viewpoints about neural improvement including mind growth, undifferentiated cell burgeoning What's more cell survival. This proof helps their part in the improvement from claiming ASD [4] Also might demonstrate those expansion for prefrontal Furthermore transient cortex that persists until adulthood [5]. Those hyper- functioning to specific neural circuits watched On extreme introvertedness might be expected should this uncontrolled Growth from claiming neural associations [6].

Other analysts bring watched expanded levels for serum ngf On know youngsters for ASD [7] What's more hyperactivity [8]. On an alternate study, serum level about ngf might have been distinguished to be fundamentally secondary in the know youngsters with ASD What's more typicallydeveloping children, which might be identified with those right on time stage about life or those affectability of the examination[9].

Our study was conducted to evaluate the levels of serum NGF in autistic children and compare them with those of normal controls.

\section{Patients and methods \\ Study design}

This is a prospective comparative study that was conducted at Benha University Hospitals, Egypt, between September 2017 to September 2019 aiming to evaluate the levels of serum nerve growth factor in autistic children.

\section{Study subjects}

The study included a total of 40 children who were divided into two groups; the patients group included 20 children with autism and the control group included 20 healthy children who were presented to Benha University clinics.

\section{Patient consent}

An informed consent was obtained from all patients and controls before participating in the study. Besides, the study was approved by the local ethical committee. 


\subsection{Methods}

Both patients and controls were subjected to complete history taking and thorough physical examination. Serum NGF was ordered for all children included in our study [10].

\subsection{Statistical analysis}

Blood samples $(3 \mathrm{ml})$ were obtained from all children included in the study. Blood was centrifuged and serum samples were stored at -80 till being analyzed. Serum samples were analyzed for NGF levels using chemikine NGF sandwich ELISA kits. Comparison between the two groups was made using student $t$ test and Chi square test.

Results were analyzed using SPSS (version 12 for Windows Chicago, IL) software. Data were presented as mean $\pm \mathrm{SD}$, average (minimum - maximum), number of patients and percent (\%). Differences between the two groups were analyzed using student's t test and Chi-square test and $\mathrm{P}<$ 0.05 was considered significant.

\section{Results}

The mean age of the included subjects was 5.1 and 4.9 years for the patients and control groups respectively. We included 13 males (65\%) and 7 females $(35 \%)$ in the patient group, while the control group included 15 males $(75 \%)$ as well as 5 females $(25 \%)$. Neither age nor gender was significantly different between the two groups. Moreover, paternal and maternal age and education were also similar between the two groups $(\mathrm{P}>0.05)$.

Table (1) Socio-demographic characters of the patients and control groups.

\begin{tabular}{|c|c|c|c|c|c|c|}
\hline \multicolumn{2}{|l|}{ Variable } & \multicolumn{2}{|c|}{$\begin{array}{c}\text { Patients } \\
(n=20)\end{array}$} & \multicolumn{2}{|c|}{$\begin{array}{c}\text { Controls } \\
(n=20)\end{array}$} & $\mathbf{P}$ \\
\hline \multirow[t]{3}{*}{ Age (ys) } & Mean \pm SD & \multicolumn{2}{|c|}{$5.1 \pm 1.2$} & \multicolumn{2}{|c|}{$4.9 \pm 1.3$} & 0.40 \\
\hline & Range & \multicolumn{2}{|c|}{ 3-12 } & \multicolumn{2}{|c|}{ 4-10 } & (NS) \\
\hline & & No. & $\%$ & No. & $\%$ & \multirow{3}{*}{$\begin{array}{c}1.0 \\
\text { (NS) }\end{array}$} \\
\hline \multirow[t]{2}{*}{ Sex } & Male & 13 & 65.0 & 15 & 75.0 & \\
\hline & Female & 7 & 35.0 & 5 & 25.0 & \\
\hline \multirow{4}{*}{$\begin{array}{l}\text { Age at } \\
\text { motherhood } \\
\text { Age of } \\
\text { fatherhood }\end{array}$} & Mean \pm SD & \multicolumn{2}{|c|}{$27.9 \pm 2.7$} & \multicolumn{2}{|c|}{$28.1 \pm 3.04$} & \multirow{2}{*}{$0.87(\mathrm{NS})$} \\
\hline & Range & \multicolumn{2}{|c|}{$23-40$} & \multicolumn{2}{|c|}{$25-38$} & \\
\hline & Mean \pm SD & \multicolumn{2}{|c|}{$31.1 \pm 2.5$} & \multicolumn{2}{|c|}{$30.0 \pm 3.3$} & \\
\hline & Range & \multicolumn{2}{|c|}{$28-43$} & \multicolumn{2}{|c|}{$28-44$} & $0.99(\mathrm{NS})$ \\
\hline \multirow{3}{*}{$\begin{array}{l}\text { Mother } \\
\text { education }\end{array}$} & Low & -- & -- & -- & -- & \multirow{3}{*}{$0.52(\mathrm{NS})$} \\
\hline & Moderate & 16 & 80.0 & 7 & 35.0 & \\
\hline & High & 4 & 20.0 & 13 & 65.0 & \\
\hline \multirow{3}{*}{$\begin{array}{l}\text { Father } \\
\text { education }\end{array}$} & Low & -- & -- & -- & -- & \multirow{3}{*}{$0.73(\mathrm{NS})$} \\
\hline & Moderate & 8 & 60.0 & 4 & 20.0 & \\
\hline & High & 12 & 40.0 & 16 & 80.0 & \\
\hline
\end{tabular}

Regarding the perinatal history of the included children, significant difference was encountered between the patients and control groups $(\mathrm{P}=0.026,0.028$ respectively).

Table (2) Comparing the patients and control groups regarding the perinatal history.

\begin{tabular}{llccccc}
\hline Variable & \multicolumn{2}{c}{$\begin{array}{c}\text { Patients } \\
(\mathbf{n = 2 0})\end{array}$} & \multicolumn{2}{c}{$\begin{array}{c}\text { Controls } \\
(\mathbf{n = 2 0})\end{array}$} & P \\
\hline $\begin{array}{l}\text { Problems during } \\
\text { pregnancy }\end{array}$ & Negative & 5 & 25.0 & 16 & 80.0 & 0.026 \\
Birth & Positive & 15 & 75.0 & 4 & 20.0 & $(\mathrm{~S})$ \\
complications & Negative & 4 & 20.0 & 17 & 85.0 & 0.028 \\
& $\begin{array}{l}\text { Positive } \\
\text { Breach }\end{array}$ & 16 & 80.0 & 3 & 15.0 & $(\mathrm{~S})$ \\
presentation & 4 & 20.0 & 1 & 5.0 & \\
& Preterm labor & 5 & 25.0 & 0 & 0.0 & \\
& Cord & 2 & 10.0 & 0 & 0.0 & \\
& $\begin{array}{l}\text { entanglement } \\
\text { Hypoxia }\end{array}$ & 5 & 25.0 & 0 & 0.0 & \\
\hline
\end{tabular}

Serum NGF was significantly elevated in the patients group compared to controls (220.0 vs. $140.0-\mathrm{p}<$ 0.001). 
Table (3) Comparing the patients and control groups regarding serum NGF.

\begin{tabular}{lcccccc}
\hline \multirow{2}{*}{ Variable } & \multicolumn{2}{c}{$\begin{array}{c}\text { Patients } \\
(\mathbf{n = 2 0})\end{array}$} & \multicolumn{2}{c}{$\begin{array}{c}\text { Controls } \\
(\mathbf{n = 2 0})\end{array}$} & $\begin{array}{c}\mathbf{Z}_{\mathbf{M w U}} \\
\text { test }\end{array}$ & P \\
\cline { 2 - 7 } & Median & Range & Median & Range & & \\
\hline Serum NGF & 220.0 & $149.5-260.9$ & 140.0 & $110.5-220.8$ & 3.66 & $\begin{array}{c}<0.001 \\
\text { (HS) }\end{array}$ \\
\hline
\end{tabular}

When it comes to the diagnostic validity of serum NGF in autism, it had a sensitivity of $85 \%$ and a specificity of $76 \%$ when its level is higher than 185.5 .

Table (4) Sensitivity and specificity of serum NGF.

\begin{tabular}{lccccccc}
\hline Serum NGF & Sens\% & Spec\% & PPV\% & NPV\% & AUC & 95\%CI & P \\
\hline$\geq 185.5$ & $85 \%$ & $76 \%$ & $79.8 \%$ & $51.5 \%$ & 0.671 & $0.70-0.79$ & $\begin{array}{c}<0.001 \\
(\mathrm{HS})\end{array}$ \\
\hline
\end{tabular}

\section{Discussion}

Those fundamental goal for our investigation might have been should explore serum ngf focuses clinched alongside mentally unbalanced kids What's more look at with the individuals done sound know youngsters. Focuses about ngf On serum bring been demonstrated will a chance to be expanded On Different neurological illnesses [11, 12].

Over our study, no noteworthy distinction might have been encountered between those tolerant Also control aggregations in regards to age, sex, or other demographic criteria. Moreover, those perinatal historical backdrop ought noteworthy Contrast the middle of the two Assemblies ( $\mathrm{P}=0.026,0.028$ respectively).

Another turkish contemplate taking care of the same point also news person that no critical Contrast might have been distinguished the middle of patients and controls in regards demographic What's more perinatal aspects [13].

Serum ngf focuses were found on a chance to be essentially higher clinched alongside mentally unbalanced Youngsters contrasted with those sound kids Previously, our ponder. Our comes about substantiated for the individuals for nelson et al. Who distinguished secondary serum focuses for Different neuropeptides (BDNF, NT3, NT4/5) including ngf What's more neurotrophins [14]. Comparative outcomes need been accounted for by others likewise $[15,16]$.

Kozlovskaia Also as much associates assessed the level about ngf in the serum from claiming 163 kids for ASD. Huge rise of the level for serum ngf might have been discovered for $79 \%$ from claiming mentally unbalanced Youngsters $(\mathrm{p}<0$. 017), Likewise compared for those controls (45 children) [18].

Riikonen Also as much partners measured the CSF ngf levels over know youngsters with puerile extreme introvertedness Also Youngsters with Rette' syndrome (RS) utilizing enzyme-linked immunosorbent test (ELISA). Their discoveries were primarily helter skelter CSF ngf levels to

extreme introvertedness and low should unimportant qualities done RS. This originated in understanding for those separate morphologic Furthermore neurochemical discoveries (brain growth, influenced mind areas, neurotransmitter metabolism) in the two syndromes. CSF ngf Might make utilized Concerning illustration a biochemical marker for separation of patients for a mental imbalance starting with the individuals with RS [16].

The introduce consider need a few limitations, Similarly as it might have been An single focal point study, and the example span might a chance to be recognized generally small, which limits the force of conclusions. Therefore, totally further upgrades need aid required done other future investigations.

\section{Conclusion}

Our preliminary findings show that serum NGF concentrations may be used as a potential diagnostic tool in autism, however, further studies including a large number of patients are required to confirm the findings.

\section{References}

[1] C.E.Robertson, S.Baron-Cohen, Sensory perception in autism. Nature Reviews Neuroscience,Vol.18(11),PP.671,2017.

[2] E.Pasciuto, S.Borrie, A.Kanell-opoulos, A.Santos, E.Cappuyns, L.D'andrea, Autism spectrum disorders: translating human deficits into mouse behavior. Neurobiology of learning and memory, Vol.124,PP.71-87, 2015.

[3] R.Pancheva, M.Georgieva, Autism spectrum disorders: neurotrophins enter the dance. Biomedical Reviews; Vol. 25 ,PP.93-9, 2014.

[4] A.J. Russo,Decreased epidermal growth factor (EGF) associated with HMGB1 and increased 
hyperactivity in children with autism. Biomarker insights,Vol.8,PP.232-239, 2013.

[5] S.Ha, I.J.Sohn, N.Kim,H.J.Sim, K.A.Cheon, Characteristics of brains in autism spectrum disorder: structure, function and connectivity across the lifespan. Experimental neurobiology ,Vol. 24 (4),PP.273-84,2015.

[6] T.Chomiak, N. Turner,B.Hu,What we have learned about autism spectrum disorder from valproic acid. Pathology research international,Vol.2013,PP.25-34,2013.

[7] G.N.Chaldarov, A.B.Tonchev, L. Aloe, NGF and BDNF: from nerves to adipose tissue, from neurokines to metabokines. Rivista di psichiatria, Vol.44(2),PP.79-87, 2009.

[8] E.Guney,M.F.Ceylan,M.Kara,N.Tekin,Z.Gok er,G.S.Dinc,Serum nerve growth factor (NGF) levels in children with attention deficit/ hyperactivity disorder (ADHD). Neuroscience letters, Vol. 560, PP.107-11,2014

[9] A.Gomez_Fernandez, MJ.de la Torre_Aguilar, M.Gil_Campos, K. Flores _Rojas, M.D.Cruz_Rico, P.Martin_Borreguero, Children With Autism Spectrum Disorder With Regression Exhibit a Different Profile in Plasma Cytokines and Adhesion Molecules Compared to Children Without Such Regression. Frontiers in pediatrics, Vol.6,PP.264,2018.

[10]A. El- Ansary, G. Bjørklund, A.M. Khemakhem ,L. Al- Ayadhi, S.Chirumbolo, AB. Bacha, Metabolism -associated markers and Childhood Autism Rating Scales (CARS) as a measure of autism severity. Journal of Molecular Neuroscience, Vol.65 (3), PP.265$76,2018$.

[11] M.Cortesi,E.Alfei,F.Barale, P.Fusar -Poli, Linking autism, regression and Landau Kleffner syndrome: Integrative role of nerve growth factor. Medical hypotheses, Vol.5 (68),PP.1178-9,2007.
[12] T.Klyushnik,N.Sergienko,E.Danilovskaya,A. Goryunova,O.Maslova, Autoantibodies to nerve growth factor in disorders of mental development in infants. Neuroscience and behavioral physiology, Vol.31(2), PP.1657,2001.

[13] N.Dinçel,A.Ünalp,A.Kutlu,A.Öztürk,N.Uran, S.Ulusoy,Serum nerve growth factor levels in autistic children in Turkish population: a preliminary study. The Indian journal of medical research, Vol.138 (6), PP.900,2013.

[14] K.B.Nelson,J.K.Grether,L.A.Croen,J.M.Damb rosia,B.F.Dickens,L.L.Jelliffe, Neuropeptides and neurotrophins in neonatal blood of children with autism or mental retardation. Annals of neurology, Vol.49 (5),PP.597606,2001 .

[15] K.Williams,M.Helmer,G.Duncan,J.Peat,C.Me llis,Perinatal and maternal risk factors for autism spectrum disorders in New South Wales, Australia. Child: care, health and development, Vol.34(2), PP.249-56,2008.

[16]R. Riikonen ,R. Vanhala, Levels of cerebrospinal fluid nerve-growth factor differ in infantile autism and Rett syndrome. Developmental medicine and child neurology, Vol.41 (3), PP.148-52,1999.

[17] J.H.Gilmore,L.F.Jarskog,S.Vadlamudi,Matern al infection regulates BDNF and NGF expression in fetal and neonatal brain and maternal-fetal unit of the rat. Journal of neuroimmunology, Vol.138(1-2),pp .49- 55, 2003.

[18] G.Kozlovskaia, T.Kliushnik, A. Goriunova, I. Turkova, M.Kalinina, N.Sergienko,Nerve growth factor auto-antibodies in children with various forms of mental dysontogenesis and in schizophrenia high risk group. Zhurnal nevrologii i psikhiatrii imeni SS Korsakova, Vol. 100(3), PP.50-2,2000. 